\title{
Comparative analysis of operational frameworks of special economic areas in Russia
}

\author{
G. F. Galiullina \\ Naberezhnye Chelny Institute, Branch of Kazan Federal University, Naberezhnye Chelny, Russia; \\ email:gulia-fag@yandex.ru
}

\begin{abstract}
There are fourteen types of special economic areas currently operating in Russia, with different federal ministries actively lobbying and then supervising the establishment of this or that type. We compare operational frameworks in different types of such areas, placing an emphasis on the areas of priority socio-economic development, which are now being established in closed towns, monotowns and the Far East. Unfortunately, Russia’s special economic areas are often criticized for their inefficacy due to the lack of systemic approach on the federal level and the conflict of interests between the key stakeholders (residents, municipalities, local companies, and local communities). Goals of regional development do not correlate with the national priorities and strategic goals. Another problem is inconsistent managerial decision-making both on the part of regional authorities and management of large enterprises. No clear, justified criteria are established to evaluate the areas' progress and no threshold values are specified. Although there is a significant concentration of special areas within certain regions, there is no integral, coordinated program or plan of action. Thus, synergetic interaction between the stakeholders is impossible. The existing procedure of establishing special areas takes into account neither the level of development of their host regions nor the quality of their development potential. These problems can be addressed through a regional industrial policy designed on the basis of the industrial-synergetic approach. Such approach makes it possible not only to focus on institutions of development and institutional transformations but also to take into account phase transformations and structural transformations in the system of areas of priority socio-economic development. The resulting organizational mechanism will be able to adjust to external uncertainties and, together with the system-forming factors, will enhance socio-economic development both on the regional and national level.
\end{abstract}

\section{KEYWORDS}

institutions of development; conflict of interests; systemic approach; comparative analysis; industrial policy; institutionalsynergetic approach; retrospective analysis

\section{ACKNOWLEDGEMENT}

This research was supported by the Russian Foundation for Basic Research (project "Strategy of Formation and Operation of Priority Development Areas Based on the Implementation of the Regional Industrial Policy" № 16-02-00073).

\section{FOR CITATION}

Galiullina, G. F. (2019)

Comparative analysis of operational frameworks of special economic areas in Russia. R-economy, 5(1), 25-37. doi: 10.15826/recon.2019.5.1.004

\section{Сравнительный анализ условий функционирования территорий с особым режимом ведения предпринимательской деятельности}

\section{Г. Ф. Галиуллина}

Набережночелнинский институт (филиал), Казанский федеральный университет, Набережные челны, Россия; еmail: gulia-fag@yandex.ru

\begin{abstract}
АННОТАЦИЯ
В настоящее время в России действует 14 типов территорий с особым режимом ведения предпринимательской деятельности. Формирование той или иной формы территориального развития активно лоббируют и затем курируют разные федеральные министерства. Сравнительный анализ выявил схожесть основных государственных преференции резидентам ранее созданных территорий с особыми условиями хозяйствования и показал ключевые отличия режима территорий опережающего социально-экономического развития, создаваемых в монопрофильных муниципальных образованиях. Результаты сравнительного и ретроспективного анализовпозволили сформулировать ведущие проблемы, которые лежат в основе малой эффективности этих территорий - это отсутствие системного подхода к созданию территорий и конфликт интересов стейкхолдеров (резиденты, действующие предприятия/аборигены, муниципалитеты, жители территории). На отсутствие системного подхода указывают следующие (c) G. F. Galiullina, 2019
\end{abstract}

\section{КЛЮЧЕВЫЕ СЛОВА}

институты развития; конфликт интересов; системный подход; сравнительный анализ; промышленная политика; институциональносинергетический подход; ретроспективный анализ 
признаки: цели территорий не взаимоувязаны с главными национальными приоритетами и стратегическими задачами развития страны; разрозненность управляющих воздействий со стороны руководства территорий и крупных предприятий; нет понимания, что подразумевается под опережающим развитием; не заданы и не обоснованы критерии опережающего развития и их пороговые значения; концентрация различных инструментов развития территорий в одной местности без разработки согласованной программы действий не включает механизм синергетического взаимодействия и не ориентировано на получение синергетических эффектов; действующий формат создания особых территорий, не учитывает уровень и качество потенциала развития данных территорий. Решение выявленных проблем предлагается реализовать в рамках территориальной промышленной политики, разработанной на основе институционально-синергетического подхода. Институционально-синергетический подход позволяет не только акцентировать внимание на институтах развития и институциональных преобразованиях, но и учитывать фазовые, структурные трансформации в системе ТОСЭР, проектировать организационно-экономический механизм, учитывающий степень неопределенности внешней среды, системообразующие и системоформирующие факторы, что в комплексе придаст необходимое ускорение социально-экономическому развитию как территории, так и региона, и страны в целом.

\section{БЛАГОДАРНОСТИ}

Работа выполнена при поддержке Российского фонда фундаментальных исследований (проект «Стратегия формирования и функционирования приоритетных направлений развития на основе реализации региональной промышленной политики» № 16-02-00073).

\section{ДЛЯ ЦИТИРОВАНИЯ}

Galiullina, G. F. (2019)

Comparative analysis of operational frameworks of special economic areas in Russia. R-economy, 5(1), 25-37. doi: 10.15826/recon.2019.5.1.004

\section{Introduction}

The first attempts to create special zones of economic development were made in Russia in the early 1990s, when the country was transitioning to a market economy. Free economic zones were established to attract foreign investment and promote Russian products on international markets by offering potential residents tax and business incentives. In 2018, in Russia, there were 14 types of SEZs used for regional development, including so-called areas of priority socio-economic development, industrial parks, and technoparks [1].

Among economists and the government some doubts have arisen, however, concerning the efficiency of these projects. The most recent type of special zones is the area of priority socio-economic development, mostly located in the Far East, monotowns and closed towns. These areas differ in terms of the regulatory incentives offered to their residents and the degree of state participation in the project. A more in-depth research is required into the mechanisms of establishing and managing these areas in order to answer such questions as: is there a need for other new types of special areas? What is the optimal approach to establishing such areas? How different should they be from the already existing types of areas?

\section{Conceptual framework}

Russian studies of special zones seek to systematize the experience of their establishment, management and performance assessment. As a rule, such areas are created to help a struggling economy and to boost the socio-economic development of a specific region. Some studies focus on certain types of zones and their characteristics.

A separate group of studies deal with conceptual questions underpinning the creation of special zones. Such studies also tend to question the very need to create special conditions for business development [2-6]. E. M. Buchvald and O. N. Valentik emphasize the fact that "the strategy of creating specific 'growth points' in the country's economy leads to greater fragmentation of its economic, business and investment space and its integral competitive environment, the latter being an essential feature of market economy. This also disrupts the country's integral social space. Inhabitants of different regions start to be divided into 'first-class' people or those who get to work at special zones and other similar areas (sufficient income, better career prospects) and 'second-class' ones, who are left outside of these areas (low income, grim career prospects)" [7].

A number of studies point out the fact that, despite their alleged differences, all types of special zones share basic parameters [8-10]. For instance, E. M. Tsygankov contends that regulations of the Free Port of Vladivostok are virtually the same as those of areas of priority socio-economic development, especially concerning tax exemptions. In fact, the concept of such areas is not new but is a mere continuation of an earlier concept of territorial development zones, with the latter stemming from an even earlier concept of special economic areas. Thus, instead of improving the 
already existing form of zones, the government has created at least four similar ones [11]. Other studies [12] demonstrate the fundamental differences in the ways regional economies function in this or that type of zones.

Some studies [13-16] draw comparisons between Russian and international models and discuss the reasons for the success of the latter. For instance, the experience of Singapore and the thirty years of China's experience (which allowed the country to achieve a high level of post-industrial development) showed that the success of special zones is determined by the two factors: firstly, the building of production facilities and social infrastructure was funded by the government and some funds were provided through public-private partnerships. Secondly, the system of incentives included economic ones such as suspension of customs duties and taxes, guarantees of cost recovery and repatriation of profits to international investors [17]. Areas of priority socio-economic development are a comparatively new instrument, although it has been partially based on Russia's previous experience of free economic zones and partially adopted from China's experience. China set up special economic zones in its southern provinces and thus managed to attract considerable investment and ensure technology transfer from foreign companies [18]. A number of studies show the low efficiency of Russian special zones and describe the problems the government faces when selecting strategic priorities for the country's socio-economic development [19-22].

V. V. Pechatkin points out the following strategic planning problems of regional development: the lack of commonly accepted methodological approaches to priority setting; prevalence of expert evaluations, which can be very subjective, in priority setting; and the lack of an adequate system for monitoring regions' competitive sustainability [23].

In the medium- and long-term, there is a discrepancy between the actual results of state projects and their expected outcomes. Due to delays in decision-making, which means that these decisions do not take into account the natural changes in internal and external environment of the region, in two- or three years' time projects change dramatically (in some cases they are even cancelled altogether) and the threshold values become unattainable. As a result, strategic planning of regional development loses some of its value and has considerable practical limitations.
Among other things, this is due to the fact that when traditional approaches are applied, strategic documents do not take into account the factors that in certain conditions may become crucial, that is, factors associated with non-linear, unbalanced development.

In order to identify strengths and weaknesses of strategic planning, we are going to conduct a retrospective analysis of Russian special zones of economic development. Comparison of the key parameters of the systems referred to as "areas of priority socio-economic development" with previously created types can bring to light the possible risks that may lead to a failure to achieve the goals and the general inefficiency of such projects.

\section{Restrospective analysis of Russia's special zones of economic development}

In contemporary Russia, since 1990, new types of zones have been created on a regular basis. Figure 1 shows this process as a spiral, indicating the dates when these types were created, supervisory bodies, and the corresponding number of zones (Figure 1). Each spiral turn indicates a new stage in the system of territorial development and presents this development as a network of zones operating in the country.

In the 28-year period, there have appeared 10 types of zones and 579 zones (as of December 2018). Different federal ministries actively lobby and then supervise the establishment of this or that type. The leader in this respect is the Ministry of Economic Development of the Russian Federation, which has high expectations for their success. Such types as zones of territorial development did not catch on; the majority of zones were deemed ineffective, and control over them was delegated to regional authorities; the majority of free economic zones were closed due to their inefficiency.

S. N. Leonov supposes that it was the struggle between federal ministries for budget funds that determined such extreme diversity of zones and explains the corresponding state policy by the government's inflated expectations of quick returns. He also points out that instead of conducting a thorough analysis of the reasons for the apparent success or failure of these projects, federal authorities chose to imitate frenzied activity by establishing more and more new zones. Each time they expected that the new instruments for supporting residents of these zones would be more successful than before [24]. 


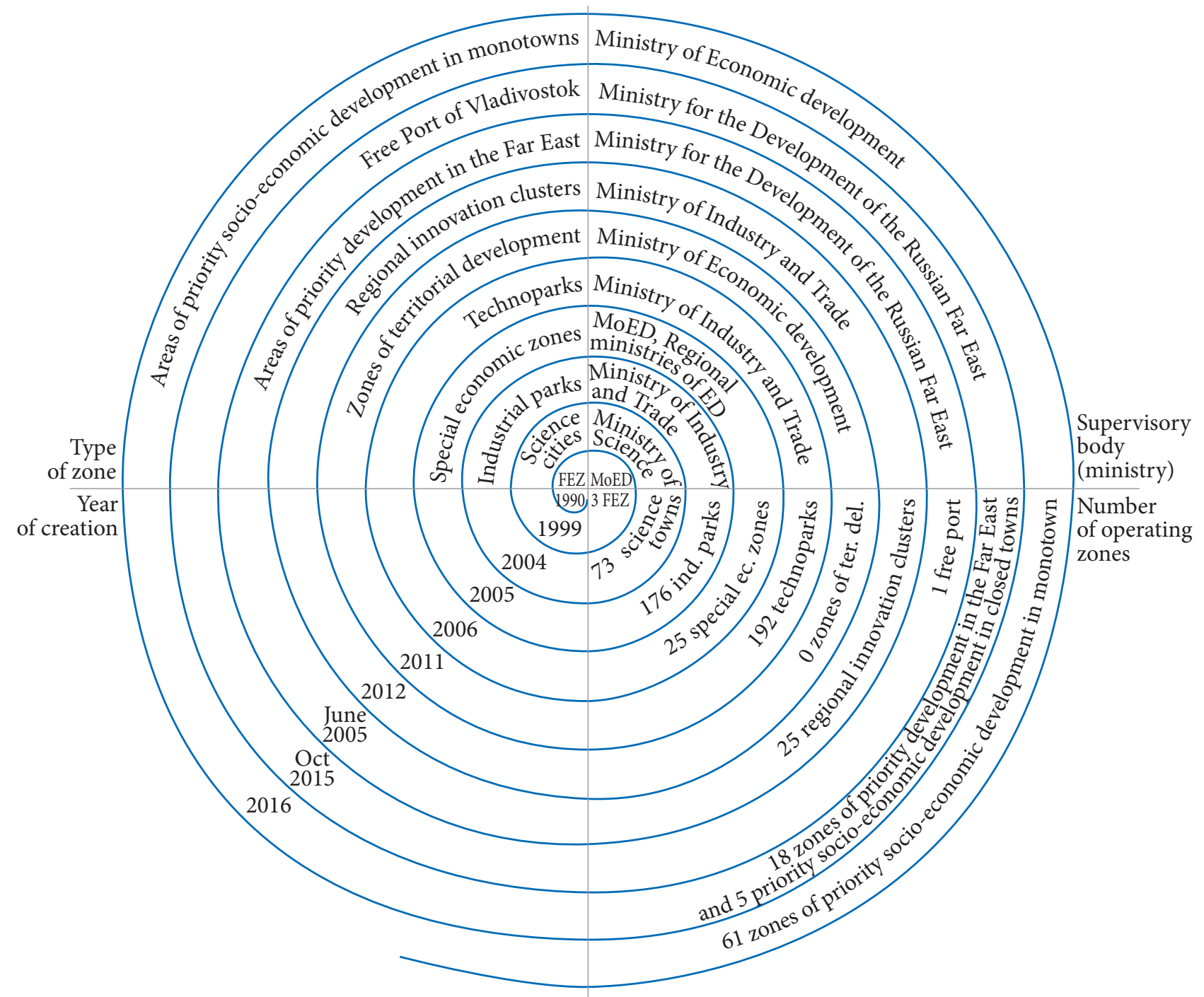

Figure 1. Development of special zones in Russia (1990-2016)

The first eleven free economic zones were opened in 1990-1992. This process was contradictory and ambiguous: on the one hand, the experience of creating free economic zones in large territories (e.g. "Yantar" in Kaliningrad region, "Nakhodka" in Primorye) was mostly negative. On the other hand, by 1996, the country already had 18 free economic zones. The main challenge inherent in implementing these projects was the lack of a coherent legislative framework, which hampered the progress: the draft of the corresponding federal law was rejected twice by the President and the already existing laws failed to provide the answers to all the questions of how these zones were to be established and managed, which led to the lack of systemic approach (the institutional conditions were not described). Thus, regions had to compete for federal subsidies as on the federal level there was no well-established mechanism of providing subsidies, guarantees and other incentives to free economic zones [25].

Since 2005, all free economic zones were closed except for two - in Magadan and Kaliningrad. In 2014, another free economic zone was created in the federal city of Sevastopol, Crimea. Since then, the government has embarked on developing a new type of zones modelled after the major Chinese zones in Shanghai and Shenzhen. Their Russian counterparts relied on the same principles as free economic zones: tax exemptions and preferential treatment, direct investment from the federal budget and so on. The Federal Law of 22.07.2005 № 116-Ф3 “On Special Economic Zones in the Russian Federation" set the following goals: to manufacture new types of products, develop knowledge-intensive sectors of economy and manufacturing industries, infrastructure, tourism and recreation. 
As of 1 January 2018, there were 25 special economic zones with 650 residents in Russia (9 of them specialize on industrial production, tourism and recreation; 6 , on innovative technologies; and 1 port). According to the official data, residents' volume of investment is about 850 billion roubles, out of which over 306 billion (36\% of the total planned investment) was provided by 102 companies with foreign capital from 34 countries. In the twelve-year period, about 290 billion roubles were invested into launching the residents' production - 446.0 million roubles were spent on each resident. Over 28 thousand jobs were created and residents paid customs duties and taxes worth of over 85 billion roubles to budgets of all levels ${ }^{1}$. An audit conducted by the Accounts Chamber in 2016 found evidence for these areas being inefficient in many respects.

- Between 2006 and 2015, the Russian government invested 186 billion roubles (122 billion allocated from the federal budget and 64 billion from regional budgets) into creating 33 special economic zones. The returns in the form of tax and customs payments were 40 billion, that is, the state got 1 rouble for every 4.65 roubles spent on such projects.

- Only $60.1 \%$ of the 214 thousand ha allocated were actually put to use.

- Out of the 758 objects of infrastructure it was planned to build, only 526 were put into operation.

- The government had to sponsor certain zones from the federal budget even though originally it had been planned that they would be funded on the regional level. At the same time, some were funded by regional budgets even though they had nothing to do with special economic zones.

- As of 1 January 2015, residents' revenues accounted for only $0.2 \%$ of the GRP in the twenty regions that hosted the zones.

- 18,177 jobs were created, which made up $72 \%$ of the target figure.

- Creation of one job cost the budget 10.2 million roubles ${ }^{2}$.

${ }^{1}$ Annual Report of the Public Joint-Stock Company "Special Economic Zones" of 2017. Retrieved from http://www.russez. ru/disclosure information/oao oez/godovie otcheti/ [Accessed September 14, 2018].

${ }^{2}$ Performance Audit Report of the Public Company "Special Economic Zones" and the Legal Entities Established for Management of Special Economic Zones in Russian Regions, in particular, the Company's Efficiency in the Use of Public Funds, Public Assets and Other Resources. Retrieved from http://www.ach.gov.ru/activities/bulleten/875/26840/ [Accessed September 14, 2018].
The ten-year history of special economic zones in Russia has shown that they have failed to become an effective instrument to support and enhance the growth of national economy. The way they were created and managed reveals a formal, irresponsible attitude, the lack of administrative discipline and the lack of accountability. As a result, no one was held responsible for the failure of these projects and no real economic effect was achieved.

Another kind of zones is "naukograd" or "science city". In 1999, a number of cities and towns with a high R\&D potential were granted this status. Over a third of them were located in Moscow region (31 "science cities", including Zelenograd, which is an administrative district of Moscow). In Central Russia, there are 8 science cities, in the Urals, nine, and in Western Siberia, seven. Moreover, there are four 'academic towns' (in Russian, "akademgorodok") of the Siberian and Far Eastern Branches of the Russian Academy of Sciences. The status of "science city" is granted for a period of five years and can be continued by the decree of the federal government. "Science cities" mainly specialize on the following:

- aerospace construction and space research (Zhukovsky, Korolev, Yubileyny, Zvezdny gorodok, Krasnoznamensk, Mirny, Znamensk, Dubna);

- electronic and radio engineering (Zelenograd, Khimki, Pravdinsk);

- automation, mechanical and instrumentation engineering (Reutov, Zarechny, Obninsk, Pereslavl-Zalessky, Raduzhny-9, Trekhgorny);

- chemistry, chemical physics and creation of new materials (Biysk, Dzerzhinsk, Pereslavl-Zalessky);

- nuclear engineering (Sarov, Zarechny, Ozersk, Snezhinsk, Trekhgorny, Lesnoy, Novouralsk, Seversk, Zheleznogorsk, Zelenogorsk);

- power engineering (Chernogolovka, Troitsk, and so on);

- biology and bio-technologies (Puschino, Protvino, settlement Borok in Yaroslavl region, two settlements Koltsovo and Krasnoobsk in Novosibirsk region).

Subsidies for "science cities" include funding allocated for R\&D; innovation projects aimed at creation and development of hi-tech production, especially those in the national priority spheres; maintenance and development of the cities' infrastructure.

Since 1990, in Russia, technoparks or industrial parks started to be used as "engines of growth". 
As a rule, they occupied former factory sites. In 2015, the first industrial park "KIP 'Master" was created, which occupied 37 thousand sq.m., the former site of the factory "Remdisel", a subsidiary of "Kamaz" corporation. As of mid-2018, the park's total area is 1,364.65 thousand sq.m., it has 260 registered residents and they have created over 5 thousand jobs ${ }^{3}$. In 2012-2018, 176 industrial parks were launched in Russia (see Table 1). There are industrial parks in Novosibirsk, Tomsk, Moscow, St. Petersburg, Nizhny Novgorod, in Moscow region and other parts of the country. The growth leaders are those located in Central and Volga federal districts, primarily Moscow region and Tatarstan. 10\% of the residents are foreign companies from 27 countries (over 80 from Germany; over 40 from the USA; and over 20 from Japan $)^{4}$.

Table 1

\section{Key performance indicators}

\begin{tabular}{|c|l|r|r|l|}
\hline № & \multicolumn{1}{|c|}{ Year } & $\mathbf{2 0 1 2}$ & $\mathbf{2 0 1 8}$ & Growth \\
\hline 1 & Number of industrial parks & 64 & 176 & 2.8 times \\
\hline 2 & Number of host regions & 27 & 51 & 1.9 times \\
\hline 3 & Industrial parks' area, ha & 14315 & 44900 & 3.1 times \\
\hline 4 & Number of residents, ths & 0.9 & 2.7 & 3.0 times \\
\hline 5 & Number of jobs created, ths & 45.0 & 160.9 & 3.6 times \\
\hline
\end{tabular}

Source: Indicators of industrial parks' performance in 2012 (based on the data provided by the web-site of the Government of Russia and the Ministry of Industry) (See: General Aspects of Industrial Policy: Key Decisions and Facts for the Six-Year Period). Retrieved from http://government.ru/ info/32124/ [Accessed 2018, 14 September], Statistical Summary of the Geo-Information System's Data on Industrial Parks. Retrieved from https://www.gisip.ru/stats sum/pdf/ru/ [Accessed December 27, 2018].

Unlike technopolises and technoparks, industrial parks usually lack R\&D infrastructure or similar facilities. Economically, industrial parks rely on lease of equipment and manufacturing facilities, tax incentives, reduced rental costs, and public-private partnership.

According to the Association of Clusters and Technoparks in the Sphere of High Technologies, in Russia there are 192 organizations that can be described as technoparks, 125 of them are located in 44 Russian regions and meet all the existing criteria and requirements. At the end of 2016, the overall revenue of the residents of 125 technoparks was 203.5 billion roubles; the

\footnotetext{
${ }^{3}$ About the company. Retrieved from http://www.kipmaster.ru/about-company/ [Accessed 2018, 14 September].

${ }^{4}$ Compiled by the author by using the data from "General Aspects of Industrial Policy: Key Decisions and Facts for the SixYear Period". Retrieved from http://government.ru/info/32124/ [Accessed September 14, 2018].
}

total amount of import-substituting production, 27 billion roubles; the number of patents granted, 900; the total amount of a resident's R\&D expenditures per one employee in 2016, 2.2 million roubles; the average level of a resident's R\&D expenditures, 147.1 thousand roubles [26].

Investment into the infrastructure of these technoparks brought some controversial results. The study of planned expenditures of Russian regions in 2013-2014 as indicated in the Plan of Establishment of Investment Objects and Objects of Infrastructure has shown that on average a Russian region spends over 1 billion roubles on industrial parks and similar, let alone the indirect expenses for the development of the related engineering infrastructure. However, as the study of the National Financial Research Institute has revealed, the occupancy rates in the majority of industrial parks do not exceed 50\%, which means that the returns received by the management companies are insufficient [5].

In 2012, the Russian government approved the establishment of 25 regional innovation clusters and provided funding from the federal budget for the programs which involve the following:

- funding activities of organizations specializing on methodological, organizational, analytical and informational support for the development of regional clusters;

- professional retraining and advanced training (including abroad) for the staff of the organizations listed as program participants;

- consulting these organizations about designing innovation investment projects;

- conducting exhibitions, fairs and similar events and participation of these organizations in such events (forums, conferences, seminars, round tables) in Russia and abroad;

- development of innovation, education, transport, energy, engineering and social infrastructure.

Since 2011, areas of territorial development started to be opened in Russia with the aim of ensuring more balanced socio-economic development of the regions and attracting investment to their economy. The Decree of the Russian Government of 16.12.2016 № 1415 "On the Approved List of Regions of the Russian Federation for Creating Zones of Territorial Development" includes twenty regions for creation of such areas. At the moment, in the majority of these regions, most of these projects are still at an early stage of development. 
In 2015, port areas of Vladivostok, Petropavlovsk-Kamchatsky, Vanino, Korsakov, and Pevek were integrated into the Free Port of Vladivostok, which offers special tax, customs, investment and other regulations ("porto franco"). The aim of the free port is to implement infrastructural projects for building and reconstruction of port terminals; warehouse complexes and other transport and logistics facilities. Russian companies, including those with foreign capital, are eligible to become residents of this zone. In order to become a resident of the Free Port of Vladivostok, a company has to meet certain requirements: it has to be registered on the territory of this zone, have a new investment project or a new kind of specialization if it an an already existing company, offer a minimum of 5 million roubles as an investment for the period no longer than three years since the date when it was included into the registry of the port's residents.

In 2016, the Accounts Chamber ${ }^{5}$ has deemed excessive and inefficient special economic zones and other similar types (innovation clusters, industrial parks, agricultural and industrial parks, technoparks, high technology parks created by the Ministry of Communications and Mass Media, tourism parks, zones of territorial development, areas of priority socio-economic development, regional special economic zones, and so on). Such instruments cannot be applied nationwide as a universal solution to all problems because this way they lose their economic significance for their residents. The more zones of territorial development of various kinds are created, the more evident becomes the lack of systemic approach and rational goal-setting in this sphere [27].

\section{Comparative analysis of operating frameworks of areas of priority so- cio-economic development and other types of zones}

In Russia, areas of priority socio-economic development have been established since 2015, first in the Far East and then in struggling monotowns. Since 2017, it has become possible to create such areas in any monotown. At the beginning of October 2018, the federal government ordered to establish 18 areas in the Far East and 63 in monotowns and closed towns. Areas of

${ }^{5}$ In ten years, special economic zones have failed to become an effective instrument for the support of Russian economy. Session of the Accounts Chamber of the Russian Federation on the Results of the Audit of Special Economic Zones in 2016. Retrieved from http:// http://www.ach.gov.ru/activities/control/26369/ [Accessed September 14, 2018]. priority development are intended to turn these territories into drivers of economic growth and are modelled after Chinese special economic zones, used to revive depressed regions [28].

We analyzes operating frameworks of areas of priority socio-economic development created in monotowns to find out if they differ significantly from those of other special economic zones (see Table 2). Far Eastern areas share many features with special economic zones: they are organized and funded by the government, managed by state companies, and the building of infrastructure is also funded from the federal budget. Their residents enjoy tax exemptions, reduced rent and insurance costs, relaxed regulations of land use, state and municipal control, access to the necessary infrastructure, and customs incentives.

It should be noted that resident companies in all types of zones are obliged to register on the territory of the city/town where the zone was created. The minimal volume of investment for potential residents of special industrial zones is 120 million roubles, for residents of port zones 120-400 million roubles. The minimal volume of capital investment for residents of areas of priority socio-economic development is set for each region individually.

Resident application procedures in all types of zones are similar: registration, submission of an investment plan, conclusion of an agreement or a reasoned refusal, preferential tax treatment. Far Eastern areas differ from special economic zones in a number of aspects: they have a wider range of authorized types of activities and can be created by uniting territories of several cities or towns.

Areas in monotowns can be set up and operate within the boundaries of the already existing towns, unlike those in the Far East and the majority of special economic zones. Areas in monotowns do not have managing companies and there is no direct infrastructure investment from the budget. Residents' investment projects are required to create a certain number of permanent jobs.

If we look attentively at the concept of special economic zones, we can notice that there is a serious discrepancy between the goals of the interested parties. For example, there exists a clash of interests between resident companies and local companies. On the market where everybody competes with everyone else one should not expect local manufacturers to be overexcited about the appearance of a new rival. On the other hand, companies that entered the market before resident 
companies already have warehouses, marketing infrastructure and so on, and they have already dealt with such problems as power supply and waste disposal. A new resident needs to tackle all of these problems and, as a result, their products are more expensive.

There are other clashes of interests, for example, between the management of resident companies and the prospective workers or local inhabitants; between regions, towns or cities that have acquired a special status; between special zones competing for residents and workforce; between newly established zones and the already existing ones, and so on.

The currently existing models of areas of priority socio-economic development aim to create "paradise" for investors by offering them tax ex- emptions and other kinds of preferential treatment and do not take into account the specific characteristics of each region. There is a common misconception that investment and creation of jobs will automatically guarantee modernization and economic growth [29].

Table 3 illustrates the key goals pursued by different stakeholders involved in creating and managing special economic zones in Russia. Let us compare them with the main national objectives and strategic goals described in the existing official documents ${ }^{6}$. For the period until 2024, the government of Russia has set the goals:

${ }^{6}$ Decree of the President of the Russian Federation of 07.05.2018 No. 204 "On National Objectives and Strategic Goals in the Development of the Russian Federation for the Period Until 2024". Retrieved from http://www.kremlin.ru/acts/bank/43027 [Accessed June 20, 2018].

Operating framework of priority development areas and other zones

Table 2

\begin{tabular}{|c|c|c|c|c|c|c|}
\hline № & Conditions & $\begin{array}{l}\text { Special economic } \\
\text { zones }\end{array}$ & $\begin{array}{c}\text { Areas of priority } \\
\text { socio-economic } \\
\text { development in } \\
\text { the Far East and } \\
\text { closed towns }\end{array}$ & $\begin{array}{c}\text { Free Port } \\
\text { of Vladi- } \\
\text { vostok }\end{array}$ & $\begin{array}{c}\text { Areas of } \\
\text { territorial } \\
\text { develop- } \\
\text { ment }\end{array}$ & $\begin{array}{l}\text { Areas of priority socio-economic } \\
\text { development in monotowns }\end{array}$ \\
\hline 1 & Period, years & 49 & 70 & & 12 & 10 \\
\hline 2 & Area & $\begin{array}{l}\text { A separate terri- } \\
\text { tory is allocated } \\
\text { within a city/town }\end{array}$ & \multicolumn{3}{|c|}{$\begin{array}{l}\text { Within one or several cities/towns in } \\
\text { one region }\end{array}$} & Within a city/town \\
\hline 3 & $\begin{array}{l}\text { Managing } \\
\text { company }\end{array}$ & \multicolumn{3}{|l|}{ Required } & \multicolumn{2}{|c|}{ Not required } \\
\hline 4 & Tax regime & \multicolumn{3}{|l|}{ Free tax zone } & \multicolumn{2}{|c|}{ No tax exemptions } \\
\hline 5 & $\begin{array}{l}\text { Infrastructure } \\
\text { investment from } \\
\text { the federal budget }\end{array}$ & \multicolumn{3}{|l|}{ Provided } & \multicolumn{2}{|c|}{ Not provided } \\
\hline 6 & Investment type & \multicolumn{3}{|c|}{ greenfield and brownfield } & \multicolumn{2}{|l|}{ brownfield } \\
\hline 7 & Limitations & $\begin{array}{l}\text { Mineral extraction } \\
\text { is not allowed, } \\
\text { except for the ex- } \\
\text { traction of mineral } \\
\text { water and other } \\
\text { resources used for } \\
\text { medical treatment; } \\
\text { It is not allowed to } \\
\text { manufacture and } \\
\text { process excisable } \\
\text { goods (except for } \\
\text { cars and motor- } \\
\text { bikes) }\end{array}$ & $\begin{array}{l}\text { Each area of } \\
\text { priority socio- } \\
\text { economic } \\
\text { development } \\
\text { has its own list } \\
\text { of authorized } \\
\text { economic } \\
\text { activities. } \\
\end{array}$ & $\begin{array}{l}\text { It is allowe } \\
\text { engage in a } \\
\text { of entrepre } \\
\text { activities th } \\
\text { legal in the } \\
\text { Federation }\end{array}$ & $\begin{array}{l}\text { ed to } \\
\text { any types } \\
\text { eneurial } \\
\text { hat are } \\
\text { e Russian }\end{array}$ & $\begin{array}{l}\text { Each area of priority development has } \\
\text { its own list of authorized 'foreign eco- } \\
\text { nomic activities'. } \\
\text { Residents are not allowed to sign con- } \\
\text { tracts with town-forming enterprises } \\
\text { and (or) to acquire revenues from selling } \\
\text { products of town-forming enterprises if } \\
\text { this revenue exceeds } 50 \% \text { of their total } \\
\text { revenue from the investment project; } \\
\text { It is not allowed to manufacture ex- } \\
\text { cisable commodities (except for cars } \\
\text { and motorbikes) and to engage in such } \\
\text { activities as extraction of crude oil and } \\
\text { natural gas, providing services in the } \\
\text { sphere of oil and gas extraction, oil re- } \\
\text { fining, wholesale and retail trade, pipe- } \\
\text { line transportation, timber logging, real } \\
\text { estate operations, and in other types of } \\
\text { economic activity which involve } 20 \% \\
\text { or more of the average staff number of } \\
\text { all organizations in the monotown }\end{array}$ \\
\hline 8 & $\begin{array}{l}\text { Use of foreign } \\
\text { labour }\end{array}$ & General regime & Facilitated visa reg & ime & $\begin{array}{l}\text { General } \\
\text { regime }\end{array}$ & $\begin{array}{l}\text { Foreign workers should not account for } \\
\text { more than } 25 \% \text { of the total workforce }\end{array}$ \\
\hline
\end{tabular}




\section{Key goals of the government and stakeholders in special economic zones}

\begin{tabular}{|l|l|l|}
\hline \multicolumn{1}{|c|}{ Levels } & \multicolumn{1}{|c|}{ Strategic goals } & \multicolumn{1}{c|}{ Stakeholders' goals } \\
\hline $\begin{array}{l}\text { Federal level } \\
\text { President, federal govern- } \\
\text { ment, state corporations }\end{array}$ & $\begin{array}{l}\text { Ensuring Russia's entrance into the top five } \\
\text { of the largest world economy, digitalization } \\
\text { of economy, and enhancement of techno- } \\
\text { logical development }\end{array}$ & $\begin{array}{l}\text { Special zones should become "growth points" and } \\
\text { “drivers of accelerated growth" by offering tax ex- } \\
\text { emptions and other kinds of preferential treatment } \\
\text { to resident companies. }\end{array}$ \\
\hline $\begin{array}{l}\text { Regional level } \\
\text { Regional government, } \\
\text { large regional companies }\end{array}$ & Sustainable development of the region & $\begin{array}{l}\text { Obtaining maximum incentives and funding from } \\
\text { the federal budget }\end{array}$ \\
\hline $\begin{array}{l}\text { Municipal level } \\
\text { Municipal authorities, } \\
\text { local inhabitants, } \\
\text { small businesses, mi- } \\
\text { cro-enterprises }\end{array}$ & High living standards & $\begin{array}{l}\text { High wage levels. } \\
\text { Developing/maintaining businesses. } \\
\text { Jobs with good working conditions. } \\
\text { Good environmental conditions/environmental } \\
\text { sustainability/ecological enhancement. } \\
\text { Good social infrastructure and housing }\end{array}$ \\
\hline
\end{tabular}

- enhance the country's technological development, increase the number of organizations engaged in technological innovation to $50 \%$;

- ensure implementation of digital technologies in economy and social sphere;

- ensure that Russia should become one of the five largest world economies, the economic growth rates exceed the global level while maintaining macroeconomic stability, in particular maintaining inflation on the level of no more than $4 \%$;

- create in the key branches of economy, primarily in manufacturing industry and in agriculture, a highly productive, export-oriented sector based on modern technologies and provided with highly qualified staff.

Interestingly enough, residents of special economic zones do not have to meet any requirements concerning the level of the technologies they apply. The analysis of areas of priority socio-economic development in monotowns and the Far East shows ${ }^{7}$ that the types of production their residents open belong to the second or third technological modes. Therefore, it becomes obvious that the purpose of special zones does not correlate with the general strategic goals of national development.

There is a gap (discrepancy) between the general strategy of regional development and narrower goals of development institutions, which means that a more comprehensive system of regional institutions is necessary. Special economic zones are not just instruments of state policy, rather they

See: Register of Residents of Priority Development Areas. Retrieved from http://erdc.ru/upload/reestr-tor.pdf [Accessed December 1, 2018]; Register of Residents of Areas of Priority Socio-Economic Development, in Russian Monotowns. Retrieved from http://economy.gov.ru/minec/activity/sections/econReg/monitoringmonocity/2016160505 [Accessed December 1, 2018]. should be seen as a part of the general strategy aimed at transforming national economy [30]. As for resident companies, they primarily seek to gain maximum funding from the state and maximum tax exemptions and other kinds of preferential treatment. The lack of cohesive business strategies combined with the desire for more preferences and funds results in a failure of resident companies to retain their status. In monotowns alone, five companies did not live up to their resident status. Some residents change their specialization sphere: for instance, "Kama Crystal Technology" in its application for the status of a resident of the priority development area "Naberezhnye Chelny" as of July 2017 indicated its intention to implement an investment project for growing artificial sapphires (included in the List of Foreign Economic Activities under the code "23.99.5 Production of synthetic corundum"). The production cost of sapphires is quite high, but their sale prices are low, which, in addition to the company's debt burden, made it alter the project's specialization and start manufacturing aluminium oxide instead. The company management explained this decision by pointing out that aluminium oxide is cheaper to produce and no less in demand than crystals [31].

However, if we look at the legal documents regulating creation and operation of special economic areas, we won't find any mention of the goals associated with high-tech manufacturing or industrial automation. On the contrary, one of the indicators used to evaluate the performance of such zones is the number of jobs created. The wage level in Russian companies is 2.5 euro per hour, which means that cheap labour is one of the main competitive advantages of special areas for attracting foreign residents (in Denmark, the average hourly pay is 25 euro and in Sweden, 14.9 euro [32]). In Russian 
regions, local inhabitants and potential workers for resident enterprises are mostly interested in the level of pay. While residents are offered some serious incentives in terms of the contributions paid to social security funds, the state does not set any requirements concerning the minimum wage level, which creates a vicious circle: the low wage level results in a low level of purchasing power of the national market, which, in its turn, affects the production output of those residents that specialize on consumer products and services.

Other problems are associated with interactions between business, state and academia such as the lack of protection of the participants' rights; the lack of unified forms of business partnership and legal framework; misuse of resources; low level of management; low quality of outcomes; failed deadlines; and so on [33]. Therefore, it is important to take a closer look at the purpose of different special areas if they are established in the same region and at their operation frameworks in order to make them able to cooperate with each other, local authorities and other stakeholders involved in regional development. It is also important to assess the efficiency of their management - each type of zone has its own management structures and there is likelihood that the managers engage in wasteful spending of state funds and added value created by the manufacturers.

Another problem faced by areas of priority socio-economic development is that there is a lack of coordinated decision-making, which means that the programs and institutions meant to ensure their development often contradict each other. In other words, there is a lack of systemic approach in strategic planning on the national, regional and local levels, which is detrimental for the efficiency of decision and policy-making and often leads to failure. Thus, we are facing a paradoxical situation here: tax exemptions are offered to direct competitors of domestic manufacturers. Moreover, federal and regional funds are spent on creating production infrastructure to attract these competitors to special economic areas. The idea that foreign companies that are offered preferential treatment would contribute to the competitiveness of local manufacturers doesn't stand up to scrutiny since foreign companies are enjoying substantial support on the part of their state authorities in promoting their production abroad [34].

In the current economic conditions there is a fierce competition for potential investors, which, on the one hand, makes city administrations and regional authorities more open for investors and, on the other hand, leads to some serious errors in judgement. For instance, "Naberezhnye Chelny" area has 21 investment projects, out of which seven are those of the enterprises which expanded their production by registering new legal entities to acquire the resident status. It cannot be argued that in difficult economic conditions tax exemptions enable some companies to complete the investment phase in their development, launch production and create jobs, but the truth of the matter is that the creation of these jobs has already been planned and they would have been created anyway, even without additional incentives on the part of the state. It means that owners of the businesses which were granted these tax exemptions were the winners while the budget was the loser as it lost money in the form of tax contributions.

While the authorities are striving to find residents for the zones they are in charge of and zones are competing for investment, the government loses sight of other, equally important issues such as the environmental impact of prospective resident enterprises and the public concerns about the harmful effects of new production. We believe that one of the main reasons for this situation is that there is a lack of carefully planned and balanced industrial policy that would formalize the strategic goals and mechanisms for optimal development of the region's industrial potential and would take into account the current trends on national and regional levels [35; 36]. Another essential question that needs to be addressed is the following: how and at what price can we achieve the technological breakthrough and accelerate growth? The answer to this question should determine the concept of industrial regional development. International scholars approach industrial policy as a mechanism for realizing the region's competitive advantages [37] and for the improvement of the industrial structure of economy $[38 ; 39]$. In the context of the fourth industrial revolution, it is impossible to enhance regional development without creating suitable infrastructure for technological innovation [40].

\section{Conclusion}

Our retrospective and comparative analysis has shown that the main problem behind the inefficiency of special economic areas is the discrepancy between the key national objectives and strategic goals and the goals pursued by these areas. Moreover, the management of such areas seeks to stimulate competition at all costs. The state offering 
preferential treatment to newly arrived companies accompanied by the call to increase competitiveness has an off-putting effect on the already existing local enterprises, which have been providing jobs for the region for a long time and paid taxes and now have to compete with foreign companies that are offered considerable tax exemptions. Such lack of coordination between the management of areas of priority socio-economic development and large enterprises leads to inefficient use of state funds, which are often invested into competing projects.

There is no clear understanding of what exactly 'priority development' is. Furthermore, there are no criteria or threshold values that would be clearly specified and based on thorough previous research. In fact, there is no knowing whether 'priority development' has been actually achieved or not. Moreover, there is no coordinated choice of instruments for regional development applied within one region and no coordinated plan of action. Such situation makes the mutual synergistic effect impossible.

When territories are granted the status of special economic areas, their development potential is all but ignored. In the conditions of constantly changing internal and external environment, the industrial policy of areas of priority socio-economic development, which relies on the institutional-synergetic approach, is aimed not only at adaptation to radical systemic changes but also at initiating the necessary changes.

In order to stimulate regional development it is essential to provide an adequate institutional foundation for this process, which is seen as a complex of socio-economic institutions, relations and instruments. Our analysis of the combined effect produced by the factors of socio-economic regional development demonstrates that traditional methods are no longer applicable as they are orientated towards managing systems either in conditions of total uncertainty (situational approach) or in conditions when a system can be maintained in a stationary mode (cybernetic approach). The distinguishing characteristic of the institutional-synergetic approach is that it models qualitative changes within the system by creating positive synergetic effects.

Development of an area as an open system can take the form of gradual transition from one phase to another, or go in leaps, or undergo crises caused by intrasystem transformations. Thus, the system is never in a state of equilibrium but there is always a multiplicity of stationary conditions. The instability of the system in this case is regarded as a potential source of growth and the basis for creating synergetic effects. An important element of the institutional-synergetic approach is the concept of self-organization, which is understood as the system's self-development and self-regulation according to the trajectory that the system should be "aware" of.

The aim of a regional industrial policy is to focus on fundamental questions associated with areas of priority socio-economic development: first and foremost, the need to coordinate policies and actions of all the stakeholders (government, business, academia, and the public) in order to ensure the region's economic and social growth. Industrial policy should be unique for each region, it should take into account its resources, its leaders' ambitions and the level of interaction between the key stakeholders.

\section{References}

1. Tsybulsky A. We notice a surge of interest among foreign investors in special economic zones. Retrieved from http://economy.gov.ru/minec/about/structure/depOsobEcZone/2017070801 [Accessed August 26, 2018].

2. Baklanov, P. Y. (2014). Territory ahead of the development: concept, structure, approaches to identification. Regionalnye issledovaniya, (3), 12-19. (In Russ.)

3. Zausaevm V., Kruchak, N, \& Bezhina, V. (2017). New model of growth for the Far East. ECO, (2), 27-35. (In Russ.)

4. Ostanin, V. A. (2017). Areas of priority socio-economic development as a creative economic space. Russia's Tax Policy in the Far East, (2). (In Russ.)

5. Smirnov, M. A. (2015). Advanced development territories: high risks and the need for an active sectoral policy of the State. Financial Analytics: Science and Experience = Finansovaya analitika: problemy i resheniya, (16), 58-68. (In Russ.)

6. Makarov, A. N. (2017). Experience Evaluation of Advanced Social and Economic Development Areas (Paradox of Development and / or Advance). Bulletin of Kemerovo State University. Series: Political, Sociological and Economic sciences = Vestnik Kemerovskogo gosudarstvennogo universiteta . Seriya: Politicheskie, sotsiologicheskie i ekonomicheskie nauki, (4), 42-47. (In Russ.) 
7. Buchvald, E. M., \& Valentik, O. N. (2015). Priority development areas: failure or illusion? ETAP: Economic Theory, Analysis, Practice, (2).

8. Krishtal, I. S. (2016). Priority development area as a factor of investment attractiveness of a region: characteristics and problems of development. Innovatsii i Investitsii, (10), 148-152. (In Russ.)

9. Osipov, V. S. (2016). Territories of priority development - new direction of institutional conditions of Russian's industry development. Journal of Economy and Entrepreneurship = Ekonomika $i$ predprinimatelstvo, (9), 852-857. (In Russ.)

10. Larchenko, O. V. (2018). Advanced development zones in single-industry urban settlements: problems and prospects (the case of the republic of Karelia). Bulletin of Kemerovo State University. Series: Political, Sociological and Economic sciences = Vestnik Kemerovskogo gosudarstvennogo universiteta. Seriya: Politicheskie, sotsiologicheskie i ekonomicheskie nauki, (2), 106-113. (In Russ.)

11. Tsygankov, E. M. (2017). Taxation issues in different forms of investment development. Nalogovaya politika i praktika, (1), 74-77. (In Russ.)

12. Ryaboshapka, A. I. (2017). Areas of priority socio-economic development and their role in stimulating the performance of small and medium-sized businesses. Academic Journal of Rostov Branch of the Russian Customs Academy, (2), 37-42. (In Russ.)

13. Alekseev, P. V. (2018). On the conditions for the successful establishment and operation of territories of priority social and economic development in the Far East of Russia. Economic sciences = Ekonomicheskie nauki, (161), 99-102. (In Russ.)

14. Iuiukina, T. I. (2018). The possibilities of application China's economic-technological development areas experience in relation to Russian's areas of advanced social and economic development. Izvestiya Sankt-Peterburgskogo gosudarstvennogo ekonomicheskogo universiteta, (2), 169-174. (In Russ.)

15. Afonin, M. G. (2017). International experience of creation and management of priority development areas in the Far Eastern Federal District. In: Theory and Practice of Management of Social and Economic Systems: Proceedings of the Sixth International Conference (pp. 9-12). Petropavlovsk-Kamchatsky: Kamchatka State Technical University. (In Russ.)

16. Kireev, A. A. (2016). Priority development areas as a factor in the development of China-Russia. Cooperation (the case of Amur Region). In: Current Challenges in the Development of China in the Process of its Regionalization and Globalization. Proceedings of the Eighth International Conference (pp. 132-139). (In Russ.)

17. Zeldner, A. G. (2016). Priority development areas: status and incentives to attract investments. Economic and Law Issues = Voprosy ekonomiki i prava, (96), 46-51. (In Russ.)

18. Kharchenkova, E. V. (2017). Effective management of the territories of priority social and economic development of the Russian Far East. Izvestiya Sankt-Peterburgskogo gosudarstvennogo ekonomicheskogo universiteta, (2), 161-164. (In Russ.)

19. Kolomenskiy, G. A., Selivanova, L. A., \& Vasilyeva, N. V. (2017). Analysis of efficiency of territories of priority socio-economic development in regional economy in Russian Federation. Herald of Education and Science Development of the Russian Academy of Natural Sciences = Vestnik obrazovaniya i razvitiya nauki Rossiiskoi akademii estestvennykh nauk, (3), 38-41. (In Russ.)

20. Sidorenko, O. V. (2017). Evaluating the Performance of Areas of Priority Socio-Economic Development. In: International Conference Proceedings 'Priorities of Development of Social Studies and Humanities, Economics and Law (pp. 128-132). (In Russ.)

21. Sinenko, O. A. (2017). Problems of assessing the effectiveness of budget expenditures in the territories with special economic status of the Far East. Bulletin of Ural Federal University. Series Economics and Management, 16(5), 803-826. (In Russ.) doi: 10.15826/vestnik.2017.16.5.039

22. Błachuciak, M. (2016). The DEA method in the evaluation of the effectiveness of the special economic zones in poland in 2014. Jagiellonian Journal of Management, 2(4), 259-273. doi: 10.4467/2450114XJJM.16.021.6090

23. Pechatkin, V. V. (2017). The concept of konkurentosposobnosti regions as the basis for the justification and implementation of strategic development priorities. Fundamental research $=$ Fundamentalnye issledovaniya, (10-1), 137-142. (In Russ.)

24. Leonov, S. N. (2017). Tools of the state regional policy in the Russian Far East. Spatial Economics = Prostranstvennaya ekonomika, (2), 41-67. (In Russ.) doi: 10.14530/se.2017.2.041-067

25. Galiullina, G. F., Kuznetsov, B. L., \& Sharamko, M. M. (2016). Areas of priority socio-economic development in monotowns: necessary conditions for implementation. In: XI International Conference Proceedings "Transformations of Russian Regions" (pp. 137-149). (In Russ.) 
26. Danilov, L. V., Golubkin, I. V., \& Labudin M. A. (2017). Third annual review "Russian technoparks - 2017”. Association of clusters and technoparks. Moscow: AKIT. (In Russ.)

27. Buchvald, E. M., \& Babkin, A. V. (2016). Industrial policy and the priorities of economic security in Russia. Transbaikal State University Journal = Vestnik Zabaikalskogo gosudarstvennogo universiteta, 22(4), 94-106. (In Russ.)

28. Turgel, I. D. (2017). New institutions for support of single- industry towns. Ekonomika $i$ politika, 2, 72-75. (In Russ.)

29. Galiullina, G., Aetdinova, R., Makarov, A., \& Vasilyev, A. (2018). Classification of territories of advanced socio-economic development. Dilemas Contemporaneos-Educacion Politica y Valores. 6(84).

30. Kotlyarova, S. N. (2014). Regional institutions: formation and development. Tomsk State University Journal of Economics = Vestnik Tomskogo gosudarstvennogo universiteta. Ekonomika, (3), 99-109. (In Russ.)

31. Mysko V., Shisterova V. Why Ilshat Fardiev's Sapphire Dreams are Broken. On-line Business Newspaper of Tatarstan. Retrieved from https://kam.business-gazeta.ru/article/378580 [Accessed September 23, 2018].

32. Klimova, N. V., \& Gulko, M. V. (2014). Foreign experience of using human resources in business (on the example of EU). Polythematic online scientific journal of Kuban State Agrarian University, (100), 1322-1335. Retrieved from http://ej.kubagro.ru/2014/06/pdf/87.pdf (In Russ.)

33. Avdeeva, I. L., Golovina, T. A., \& Belikova, Y. V. (2017). Management of the processes of functioning of territories of advanced development as a factor in ensuring the sustainability of regional economic systems. St. Petersburg State Polytechnical University Journal. Economics = Nauchno-tekhnicheskie vedomosti SPbGPU. Ekonomicheskie nauki. 10(6), 84-95. (In Russ.) doi: 10.18721/JE.10608

34. Galiullina, G. F., \& Fatkhutdinov, A. N. (2018). Urgency of development of industrial policy of territories of advanced development. Managenebt of Economic Systems: Scientific Electronic Journal = Upravlenie ekonomicheskimi sistemami: elektronnyi nauchnyi zhurnal, (5), 25. (In Russ.)

35. Galiullina, G. F., Sharamko, M. M., \& Andreeva, F. I. (2017). Institutional-synergetic approach in benchmarking of territorial industrial policy. R-Economy, 3(3), 167-175. doi: $\underline{10.15826 /}$ recon.2017.3.3.019

36. Turgel, I. D., Bozhko, L. L. \& Xu, Linshui (2016). Government support of single-industry towns in Russia and Kazakhstan. Vestnik Finansovogo universiteta, 20(2), 22-32. (In Russ.)

37. Lin, J. Y. (2012). New structural economics: a framework for rethinking development and policy. The World Bank.

38. Gahlen, B. (1981). Strukturpolitik und Soziale Marktwirtschaft. In: Issing, O. (Hrsg.) Zukunfsprobleme der sozialen Mar-ktwirtschaft. Berlin, 853-871.

39. Pack, H. \& Saggi, K. (2006). The case for industrial policy: a critical survey. The World Bank.

40. Putna, M. (2012). New industrial policy. International Journal of Business and Management Studies, 1(2), 463-467.

\section{Author}

Gylyia F. Galiullina - Cand. Sc. (Economics), Associate Professor, Department of Economic Theory and Economic Policy, Naberezhnye Chelny Institute, Branch of Kazan Federal University (1/18 Complex 1, Naberezhnye Chelny, 423812, Russia); e-mail: gulia-fag@yandex.ru

ARTICLE INFO: received November 17, 2018; accepted January 14, 2019

\section{Информация об авторе}

Галиуллина Гыльия Фагимовна - кандидат экономических наук, доцент кафедры экономической теории и экономической политики, Набережно-Челнинский институт, филиал Казанского федерального университета (423812, Россия, Набережные Челны, Комплекс 1, 1/18); e-mail: gulia-fag@yandex.ru

ИНФОРМАЦИЯ О СТАТЬЕ: дата поступления 17 ноября 2018 г.; дата принятия к печати 14 января 2019 г. 